\title{
Multivariate statistical analysis to characterize/discriminate between anthropogenic and geogenic trace element occurrence in the Campania Plain, Southern Italy
}

\author{
Gianluigi Busico $^{\mathrm{a}}$, Emilio Cuoco ${ }^{\mathrm{a}}$, Nerantzis Kazakis ${ }^{\mathrm{b}, *}$, Nicolò Colombani $^{\mathrm{c}}$, Micòl Mastrocicco ${ }^{\mathrm{a}}$, Dario Tedesco ${ }^{\mathrm{a}}$, \\ Konstantinos Voudouris ${ }^{\mathrm{b}}$ \\ a Department of Environmental, Biological and Pharmaceutical Sciences and Technologies, University of Campania "Luigi Vanvitelli", Via Vivaldi 43,81100 Caserta, Italy \\ ${ }^{\mathrm{b}}$ Department of Geology, Laboratory of Engineering Geology \& Hydrogeology, Aristotle University of Thessaloniki, 54124 Thessaloniki, Greece \\ ${ }^{c}$ Department of Life Sciences and Biotechnology, University of Ferrara, Via Luigi Borsari 46, 44121 Ferrara, Italy
}

\section{A R T I C L E I N F O}

Article history:

Received 15 July 2017

Received in revised form 8 October 2017

Accepted 13 November 2017

Available online xxx

Keywords:

Factor analysis

Trace elements

Seawater intrusion

Anthropogenic inputs

Geogenic sources

Groundwater

\begin{abstract}
A B S T R A C T
Shallow aquifers are the most accessible reservoirs of potable groundwater; nevertheless, they are also prone to various sources of pollution and it is usually difficult to distinguish between human and natural sources at the watershed scale. The area chosen for this study (the Campania Plain) is characterized by high spatial heterogeneities both in geochemical features and in hydraulic properties. Groundwater mineralization is driven by many processes such as, geothermal activity, weathering of volcanic products and intense human activities. In such a landscape, multivariate statistical analysis has been used to differentiate among the main hydrochemical processes occurring in the area, using three different approaches of factor analysis: (i) major elements, (ii) trace elements, (iii) both major and trace elements. The elaboration of the factor analysis approaches has revealed seven distinct hydrogeochemical processes: i) Salinization $\left(\mathrm{Cl}^{-}, \mathrm{Na}^{+}\right)$; ii) Carbonate rocks dissolution; iii) Anthropogenic inputs $\left(\mathrm{NO}_{3}{ }^{-}, \mathrm{SO}_{4}{ }^{2-}, \mathrm{U}, \mathrm{V}\right)$; iv) Reducing conditions $\left(\mathrm{Fe}^{2+}, \mathrm{Mn}^{2+}\right)$; v) Heavy metals contamination ( $\mathrm{Cr}$ and Ni); vi) Geothermal fluids influence $\left(\mathrm{Li}^{+}\right)$; and vii) Volcanic products contribution (As, Rb). Results from this study highlight the need to separately apply factor analysis when a large data set of trace elements is available. In fact, the impact of geothermal fluids in the shallow aquifer was identified from the application of the factor analysis using only trace elements. This study also reveals that the factor analysis of major and trace elements can differentiate between anthropogenic and geogenic sources of pollution in intensively exploited aquifers.
\end{abstract}

\section{Introduction}

Groundwater constitutes the main resource of fresh water for humans (Niu et al., 2017), and shallow aquifers are the most accessible and exploited resources for drinking purposes, even thou they are more susceptible to contamination than confined aquifers. Groundwater quality depends on both natural processes and anthropogenic activities (Foster and Chilton, 2003). Water-rock interaction, mineral dissolution, residence time of groundwater, flow paths, mixing among different water bodies and human exploitation are the main deterioration factors of groundwater quality (Belkhiri et al., 2010). Thus, to clearly define the ongoing hydrogeochemical processes within an aquifer is a challenging task, since large data sets and advanced methodologies are required. Multivariate statistical analysis such as the factor analysis (FA), the principal component analysis (PCA), the analysis of variance (ANOVA) and the cluster analysis, represent sound tools to detect and explain hydrogeochemical factors

\footnotetext{
? This paper has been recommended for acceptance by Dr. Harmon Sarah Michele

* Corresponding author.

Email address: kazanera@yahoo.com (N. Kazakis)
}

(Locsey and Cox, 2003) governing the chemical composition of groundwater (Corniello and Ducci, 2014). These statistical tools allow to discriminate between anthropogenic and geogenic sources (Cuoco et al., 2015b; Kim et al., 2009a; Mastrocicco et al., 2016; Pereira et al., 2003) and to manage large datasets without losing critical information and giving an accurate hydrochemical assessment of the studied aquifers (Voudouris et al., 2000). In contrast, chemical analysis, simple plots and correlation between different elements can provide limited understanding of the environmental distribution of contaminants (Einax et al., 1997). Nevertheless, the statistical tools and presentation methods are strongly dependent on the goals of each study and the quality and quantity of data available.

Recent studies focused on the capability of FA to identify hydrological processes for specific areas (Huang and Wang, 2017; Yang et al., 2016) and in different hydrological basins, under different hydrogeological conditions (Kazakis et al., 2017a). However, questions have arisen regarding the number of dissolved species that FA should include. Therefore, in order to test the response of FA using different combinations and number of dissolved species, the Campania Plain (CP) in Southern Italy was selected and studied since it hosts an aquifer characterized by a complex hydrochemical status, well represented in a large and consistent data set. 
The CP is characterized by high spatial hydrogeological and geochemical heterogeneities. In fact, several processes due to the coexistence of different geological units and human activities affect the mineralization of groundwater, which is the primary water resource within the CP. Anthropogenic sources of pollution are mainly due to extensive urbanization, farming, agriculture practices and industries, while geothermal activities, volcanic products and saline sediments constitute the natural sources of geogenic pollution (Corniello et al., 2007). Indisputably, it is a challenge to characterize this complex and interconnected hydrochemical regime. Multivariate statistical analysis and advanced statistics constitute the most appropriate tool to be used even thou they require a large, robust and consistent dataset to be considered.

To summarize, the aim of this research is twofold: (i) to distinguish between natural and anthropogenic processes affecting groundwater focusing on trace elements and (ii) to test the response of FA using different combinations and number of dissolved species. A GIS environment was used to improve the visualization of the results for the multivariate statistical analysis and to depict water-rock interaction and anthropogenic processes in the study area.

\section{Materials and methods}

\subsection{Study area}

The Campania Plain (CP) is limited to the $\mathrm{W}$ by the Tyrrhenian Sea, to the N-NE by Massico Massif and Roccamonfina Volcano, to the $\mathrm{S}$ by the Phlegrean Fields and Mt. Vesuvio and to the E by the Maggiore, Tifatini and Avella Mountains (Fig. 1). The geological evolution of the graben hosting the $\mathrm{CP}$ begun in the upper Pliocene and proceeded during the Holocene with a critical extensive-tectonic stress (Casciello et al., 2006). The tectonic processes allowed the development of several volcanic centres (Roccamonfina, Phlegrean Fields and Somma-Vesuvio) located in the most depressed areas, at the graben borders (Rolandi et al., 2003). The carbonate bedrock of the Apennine chain is buried by marine clays and sands having the upper limit between 90 and $20 \mathrm{~m}$ below sea level, the overlying unit is made of Phlegrean volcano-clastites and volcanic sediments from others volcanic centres, made of trachytic-phonolithic pyroclastic materials, sands and cinerite reworked in subaqueous environment (De Vivo et al., 2001; Santangelo et al., 2017). The Holocene sediments, outcropping in the middle of the $\mathrm{CP}$, are irregular successions of clays, silts and peat beds deposited by the Volturno River, while to-
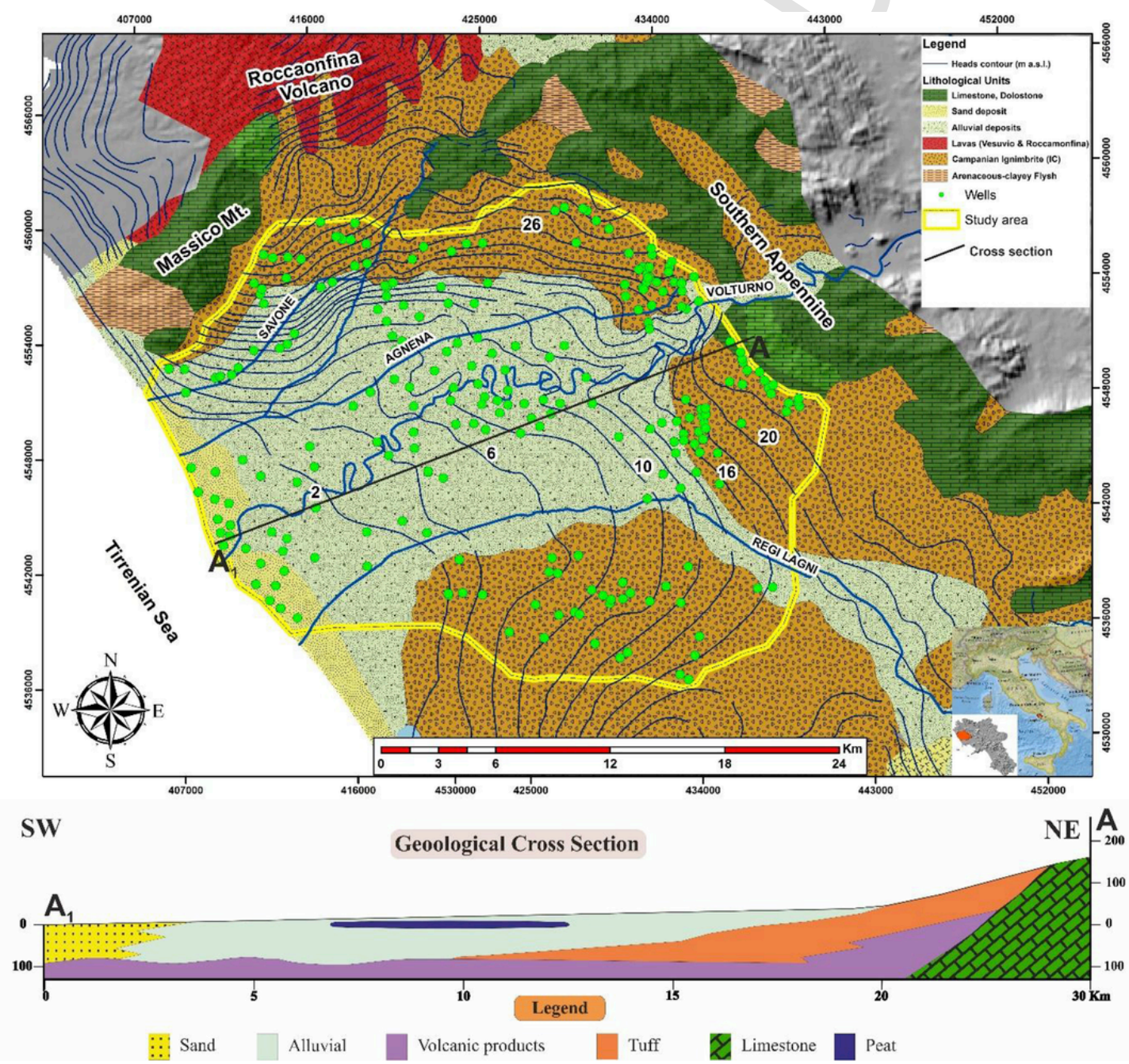

Fig. 1. Geological settings of the study area. 
ward the coast dunes and sandbars are present (Amorosi et al., 2012). In the Southern part of the plain, the outcropping unit is an irregular succession of pozzolans, cinerites and sandy pyroclastites due to the Phlegrean Fields activity. The shallow aquifer of the study area is mainly hosted in the volcanic and alluvial sediments (section in Fig. 1 ), it is recharged by the local infiltration of rainwaters and fed by lateral inflows coming from karst and volcanic aquifers at the eastern and northern boundaries of the $\mathrm{CP}$. The regional groundwater flow direction is from East to West (Allocca et al., 2007).

The CP covers approximately $700 \mathrm{Km}^{2}$ and has a population of more than 1 million inhabitants. The area shows a heterogeneous land use: (i) the urban area covers approximately $20 \%$ of the territory, (ii) the agricultural land is about $75 \%$ (where a variety of different crops are cultivated), and (iii) forests and pastures occupy the remaining territory, mainly on the ridges of the massifs surrounding the plain.

\subsection{Sampling techniques}

Within the boundaries shown in Fig. 1, 244 water samples were collected from agricultural, residential and municipal wells after purging at least three well volumes. Coordinates for all samples were recorded using a portable GPS. Electrical conductivity (EC), temperature $(\mathrm{T})$ and $\mathrm{pH}$ values were measured in situ using a multi-parameter Hanna Hi 991300 probe. All samples were prepared for laboratory analysis using 500 and $50 \mathrm{ml}$ PET bottle. In the geochemical laboratory of the University of Campania "Luigi Vanvitelli" the major ions $\mathrm{Ca}^{2+}, \mathrm{Mg}^{2+}, \mathrm{K}^{+}, \mathrm{Na}^{+}, \mathrm{Cl}^{-}, \mathrm{SO}_{4}{ }^{2-}, \mathrm{NO}_{3}{ }^{-}$were determined with a Dionex IC-120 ion chromatographer using four calibrations standards $(0.5,5$, $\left.25,50 \mathrm{mg} \mathrm{L}^{-1}\right)$. Precision and accuracy were tested trough repeated measurements of certified standard solutions $\left(\mathrm{MERK}^{\circledR}\right)$ at different ion concentrations with a range comparable to that of the analysed samples. The relative percentage error for precision was $7 \%$ for $\mathrm{Na}^{+}$, $\mathrm{K}^{+}$and $\mathrm{Ca}^{2+}, 5 \%$ for $\mathrm{Mg}^{2+}$ and $\mathrm{SO}_{4}{ }^{2-}$, and below $5 \%$ for other anions. A $100 \mathrm{ml}$ aliquot of each sample, intended for $\mathrm{HCO}_{3}{ }^{-}$measurement, was titrated with certified $0.1 \mathrm{~mol} \mathrm{~L}^{-1} \mathrm{HCl}$. Trace elements $(\mathrm{Fe}$, $\mathrm{Mn}, \mathrm{Zn}, \mathrm{B}, \mathrm{V}, \mathrm{Li}, \mathrm{U}, \mathrm{Cr}, \mathrm{Ba}, \mathrm{Sr}$, As and Ni) were determined using an Agilent 7500 CE ICP-MS with intact interference reaction cell according to Cuoco et al. $(2017 \mathrm{~b}, 2013)$. Other elements were not considered since they have never been detected above the detection limit in the 244 samples considered. ICP-MS analyses were tested trough Interference Check Solutions (AGILENT ${ }^{\circledR}$ ) in order to check the efficient functioning of the system. The instrumental drift was checked trough Y-Tb internal standard solution $\left(\mathrm{AGILENT}^{\circledR}\right)$. Accuracy and precision were checked following EPA method 200.8 and the relative percentage error for precision was less than $7 \%$. The overall precision of the chemical analyses was checked by ionic balance, which was within $\pm 5 \%$.

\subsection{Multivariate statistical analysis and graphical methods}

In this study, the multivariate statistical analysis was chosen in order to determine the hydrogeochemical processes in the CP. More specifically, the statistical technique examines the relationship between variables detected in several samples, which represent a list of cases, and gives back a list of significant factors that assemble the initial variables. In this work, FA was applied under three different approaches: (i) using major ions (FA-A), (ii) using trace elements (FA-B), (iii) and using both (FA-C). Hence, the comparison of FA results can spotlight how processes that occur in the $\mathrm{CP}$ are described by different data sets. Moreover, natural and anthropogenic activities can be distinguished. The R-type FA was applied to reduce the large database (244 samples), organize data in groups with similar charac- teristics and identify the weight and score of each parameter. New and small groups of factors were created summarizing the initial variables (Anazawa and Ohmori, 2005; Brown, 1998; Voudouris et al., 1997, 2000).

The correlation coefficient (Pearson) was used to identify the degree of dependency between variables (Batabyal, 2014). The normal distribution of the data set was verified applying the Kolmogorov-Smirnov test (K-S test).

The Varimax rotation through the Kaiser normalization procedure was selected, whereas variables exhibiting a rotated loading $>0.5$ were considered significant since the Kaiser-Meyer-Olkin (KMO) coefficient need to be higher than 0.5 (Kumar, 2014; Liu et al., 2003). The use of factor scores and of Ordinary Kriging (OK), according to Wang et al. (2001), allows to identify every single process and shows how using more data for geochemical characterization can return a higher resolution in identifying and locating the natural and anthropogenic processes acting on the area. Analysing the score, negative values represent the areas not affected by a given process, instead positive or near zero values represent the areas affected by the process which each factor represents. According to Ujević Bošnjak et al. (2012) variables and factor loading correlations (absolute values) ranging between \pm 0.75 and \pm 1.0 are strong, between \pm 0.5 and \pm 0.75 are moderate, and between \pm 0.5 and \pm 0.3 are weak.

All groundwater data were also plotted in the Piper diagram (Piper, 1944), which is usually employed to interpret hydrochemical data by the visual description and classification of water samples in different water-type categories (Back and Hanshaw, 1965).

\section{Results}

\subsection{Geochemical setting of shallow groundwater}

The CP is characterized by complex hydrochemical characteristics and by the coexistence of both anthropogenic and geogenic pollution sources (Cuoco et al., 2015b). A summary table with descriptive statistic of all dissolved species included in the elaboration is shown in Table S1.

The chemical composition of groundwater samples has been plotted in the Piper diagram of Fig. 2. Groundwater has a $\mathrm{Ca}-\mathrm{HCO}_{3} \mathrm{com}-$ position with $45 \%$ of samples showing a $\mathrm{Ca}^{2+}$ ranging between $50 \%$ and $79 \%$ of total cations, $47 \%$ with $\mathrm{Ca}^{2+}$ between $30 \%$ and $50 \%$ due to alkali ions increasing in solution (see cations ternary diagram in Fig. 2). The detected compositions are related to the hydrodynamics of shallow groundwater within the $\mathrm{CP}$, in agreement with Cuoco et al. (2015a). In fact, the original $\mathrm{Ca}-\mathrm{HCO}_{3}$ composition of groundwater coming from lateral carbonate massifs, undergoes a gradual alkali ions enrichment along the flow path, due to the water-rock interaction with lithologies rich in alkali elements present in the $\mathrm{CP}$. This explains why over $70 \%$ of sampled waters tend to a $\mathrm{Ca}(\mathrm{Na})-\mathrm{HCO}_{3}$ composition. Exceptions are in $8 \%$ of samples, where the increasing $\mathrm{Na}-\mathrm{Cl}$ component detected in the costal area and in the volcanic sediments (Parete-Agro Aversano area), leads to a $\mathrm{Na}(\mathrm{K})-\mathrm{HCO}_{3}$ composition due to the lack of inflow from the surrounding carbonate aquifers. Finally, the $\mathrm{SO}_{4}{ }^{2-}$ increase detected in the upper part of the Piper diagram is due to highly impacted groundwater, affected by intense human activities (Cuoco et al., 2015b).

\subsection{Multivariate statistical analysis}

In order to identify all the possible geochemical processes in the study area, three different approaches of FA analysis were performed: (i) FA-A, (ii) FA-B and (iii) FA-C. In the first approach (FA-A) the major ions of $\mathrm{Ca}^{2+}, \mathrm{Mg}^{2+}, \mathrm{K}^{+}, \mathrm{Na}^{+}, \mathrm{Cl}^{-}, \mathrm{SO}_{4}{ }^{2-}, \mathrm{NO}_{3}{ }^{-}$, as well as EC 




Fig. 2. Piper plot of ion concentrations for the study area.

and $\mathrm{pH}$ were used as variables. The number of factors was chosen following the Kaiser criterion (Kaiser, 1958) and hence, three factors emerged from the analysis with a KMO coefficient of 0.433 under a $95 \%$ confidence interval and with a total variance explained equal to $75 \%$. The correlation matrix of the dissolved species is shown in Table S2 and the results of FA-A together with factors identification is shown in Table 1.

The first factor (1-A) explains $29 \%$ of total variance and presents a positive correlation between $\mathrm{Cl}^{-}, \mathrm{Na}^{+}, \mathrm{pH}, \mathrm{EC}$ and $\mathrm{K}^{+}$with a medium strength. A map of the spatial distribution of Factor 1-A is shown in Fig. 3. The spatial distribution of Factor 1-A differentiates the area in two zones. The first is characterized by significantly negative loadings (blue shade) and the second one where the process becomes stronger (yellow to red shade). Factor 2-A consists of three species, $\mathrm{HCO}_{3}{ }^{-}$, $\mathrm{Ca}^{2+}$ and $\mathrm{Mg}^{2+}$ and explains $29 \%$ of total variance (Fig. 4). These three ions are enriched in solution from the water-carbonate rocks interaction. Factor 3-A explains $17 \%$ of variance and has a strong-moderate correlation among $\mathrm{NO}_{3}{ }^{-}, \mathrm{SO}_{4}{ }^{2-}$ and $\mathrm{K}^{+}$. This factor should explain the human impact on the area (Fig. 5).

FA-B was performed using trace elements ( $\mathrm{Li}, \mathrm{B}, \mathrm{V}, \mathrm{Cr}, \mathrm{Mn}, \mathrm{Fe}$, $\mathrm{Ni}, \mathrm{As}, \mathrm{Rb}, \mathrm{Sr}, \mathrm{U}$ and $\mathrm{Ba}$ ) for the same database. In this case the $\mathrm{KMO}$ coefficient value is 0.592 , which is higher than FA-A. Five fac-

Table 1

Factor score for FA-A.

\begin{tabular}{llll}
\hline FA-A & Component & & \\
\hline & 1 & 2 & 3 \\
\hline $\mathrm{pH}$ & 0.674 & -0.066 & -0.250 \\
$\mathrm{EC}$ & 0.690 & 0.650 & 0.252 \\
$\mathrm{HCO}$ & 0.423 & 0.761 & -0.250 \\
$\mathrm{Cl}_{3}$ & 0.804 & 0.341 & 0.124 \\
$\mathrm{NO}_{3}$ & -0.255 & -0.192 & 0.841 \\
$\mathrm{SO}_{4}$ & 0.109 & 0.414 & 0.683 \\
$\mathrm{Na}_{\mathrm{K}}$ & 0.899 & 0.244 & 0.082 \\
$\mathrm{Mg}$ & 0.441 & -0.047 & 0.529 \\
$\mathrm{Ca}$ & 0.303 & 0.836 & 0.004 \\
\hline
\end{tabular}

tors showed eigenvalues higher than 1 , explaining $69 \%$ of the total variance (Table 2).

In the first factor (1-B), explaining $19 \%$ of the total variance, $\mathrm{Sr}$, $\mathrm{Ba}$ and $\mathrm{B}$ are present, with $\mathrm{Sr}$ showing the highest loadings. The weighting for Factor 1-B is positive for all the variables except for $\mathrm{As}, \mathrm{Cr}$ and $\mathrm{V}$. The source of Sr might be the dissolution (weathering) of carbonate rocks or Sr-bearing clay materials (Zieliński et al., 2017); while $\mathrm{B}$ and $\mathrm{Ba}$ could be the result of contacts with reworked igneous sediments (Mokrik et al., 2009), present in the central part of the CP. Factor 2-B shows a strong correlation between Fe and Mn. The mobilization of these species demands reducing conditions of the aquifer. Factor 3-B (13\% of the total variation) shows high loading of $\mathrm{Cr}$ and $\mathrm{Ni}$, which could have natural origin. Factor 4-B (13\% of the total variance) indicates the interaction of volcanic rocks and groundwater, since only $\mathrm{Rb}$ and As show a high correlation. Factor 5-B, where $\mathrm{Li}$ has the highest loading, explains the process occurring in a particular region of the area where a hydrothermal system is present (Fig. S1). This system, located in the Mondragone plain (Cuoco et al., 2015a), shows high Li concentrations in thermal waters (Sánchez-Martos et al., 2002). In fact, the mobility of Li is strongly related to higher temperatures and therefore, is assigned to geothermal fluids (Chan et al., 1994).

The last application of FA (FA-C) was performed including major ions, trace element and physical properties. The KMO coefficient value is $0.597(>0.5)$ which is statistically significant and the method is confirmed to be valid. Six factors showed eigenvalues higher than one, explaining $69 \%$ of the total variance. All factors for FA-C are shown in Table 3.

In the first factor (1-C), which explains $20 \%$ of the total variance, $\mathrm{Na}^{+}, \mathrm{Cl}^{-}, \mathrm{EC}$ and $\mathrm{B}$ show the highest loadings. Factor 1-C explains a process similar to Factor 1-A and has the same spatial distribution (Fig. 3).

Factor 2-C is also similar with Factor 2-A (Fig. 4) including $\mathrm{Sr}$ and $\mathrm{Li}$ in the variables with high loading. Factor $3-\mathrm{C}(9.8 \%$ of the total variation) indicates anthropogenic activities mainly related to fertilizers and leaching sewers. Remarkably, $\mathrm{V}$ and $\mathrm{U}$ are included in this factor having high correlation with $\mathrm{K}, \mathrm{NO}_{3}{ }^{-}$and $\mathrm{SO}_{4}{ }^{2-}$.

Factor 4-C (8.2\% of the total variance) shows high loadings for $\mathrm{Fe}$ and Mn. Similarly to Factor 2-B, this factor represents reducing conditions in groundwater.

$\mathrm{Cr}$ and $\mathrm{Ni}$ have high correlation in Factor 5-C, describing the same process of Factor 3-B.

Finally, Factor $6-\mathrm{C}(6.2 \%$ of the total variance $)$ indicates the interaction of volcanic rocks with groundwater, where $\mathrm{As}$ and $\mathrm{Rb}$ have the highest loading.

Results of this study clearly show that the number of variables (dissolved species) strongly affects the application of FA. The application of FA using only major ions has a KMO in the edge of acceptance, while using the entire data set the KMO is substantially improved. However, even the second FA application, using only trace elements, had remarkably distinguished the mobilization of Li highlighting the influence of geothermal fluids in the area.

\section{Discussion}

Hydrogeochemistry of shallow aquifers in the CP has been described in Cuoco et al. (2015a), but in this study the higher density of groundwater samples provides a better identification of the different processes occurring in the aquifer and characterizing the hydrogeochemical regime of the studied area. The elaboration and comparison of the three FA approaches have revealed seven distinguishable hydrogeochemical processes in the aquifer, which can be summarized as follow: i) Salinization $\left(\mathrm{Cl}^{-}, \mathrm{Na}^{+}\right)$, ii) Carbonate rocks influences, 


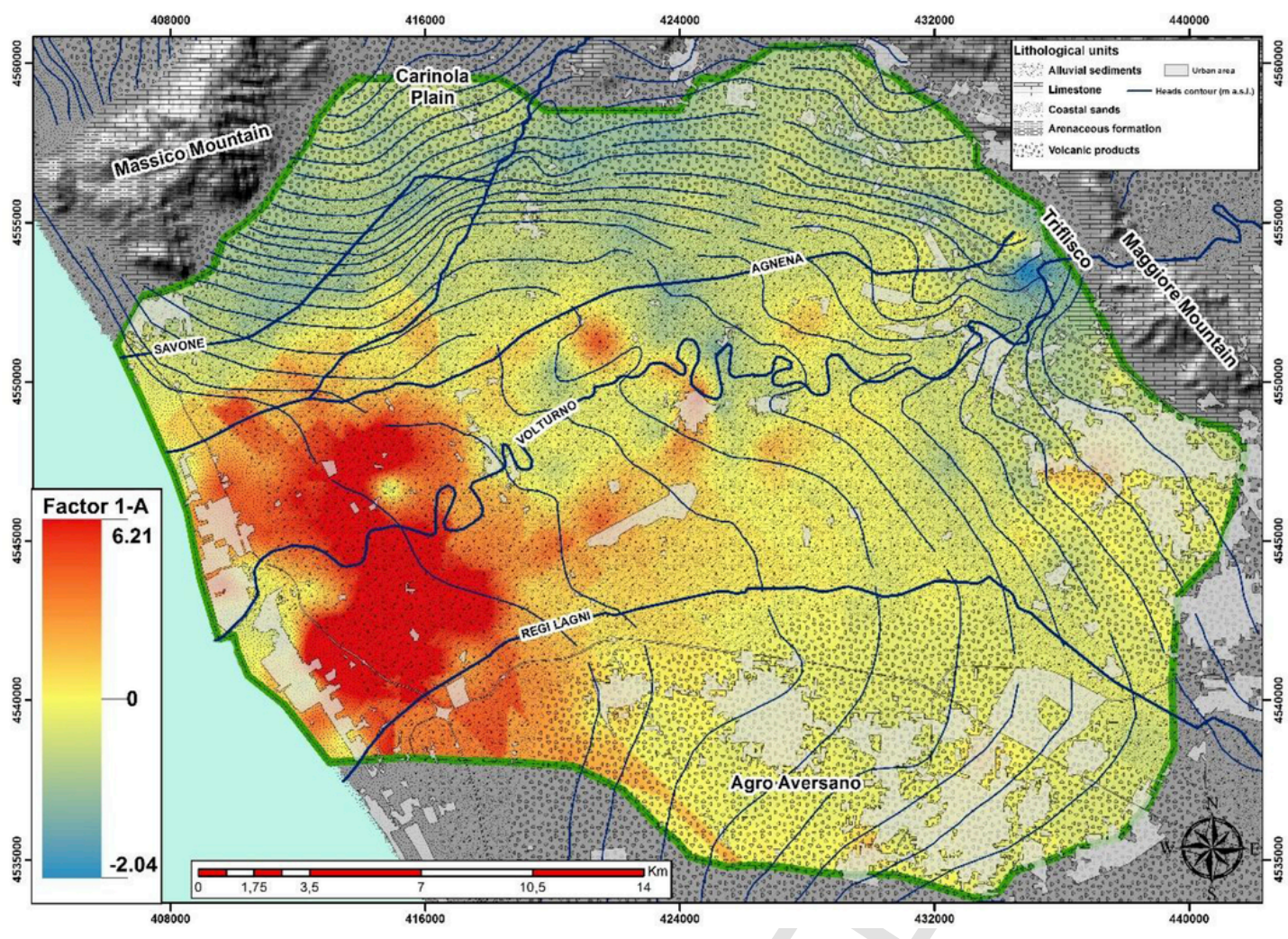

Fig. 3. Spatial distribution of Factor 1 (FA-A).

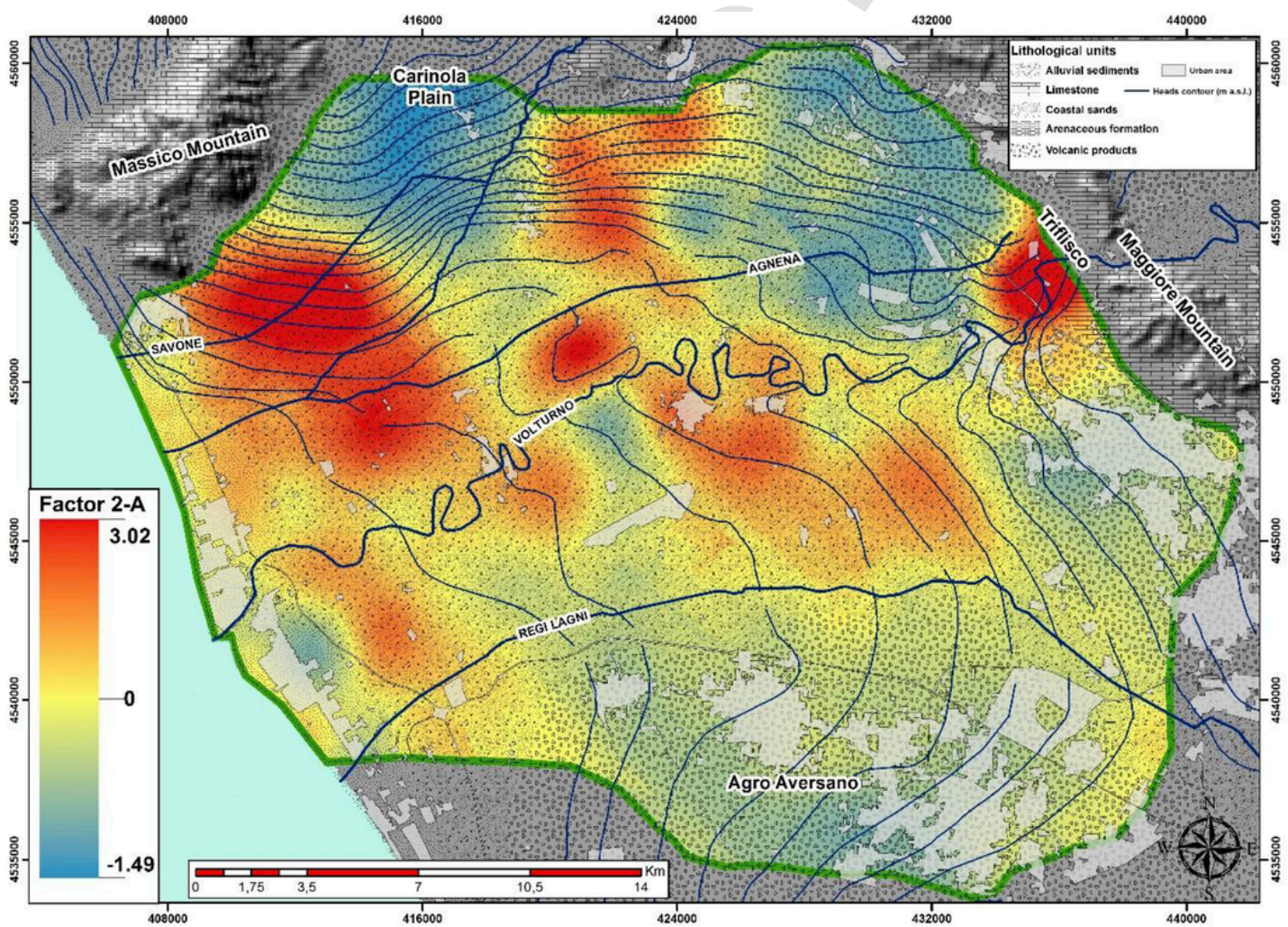

Fig. 4. Spatial distribution of Factor 2 (FA-A). 


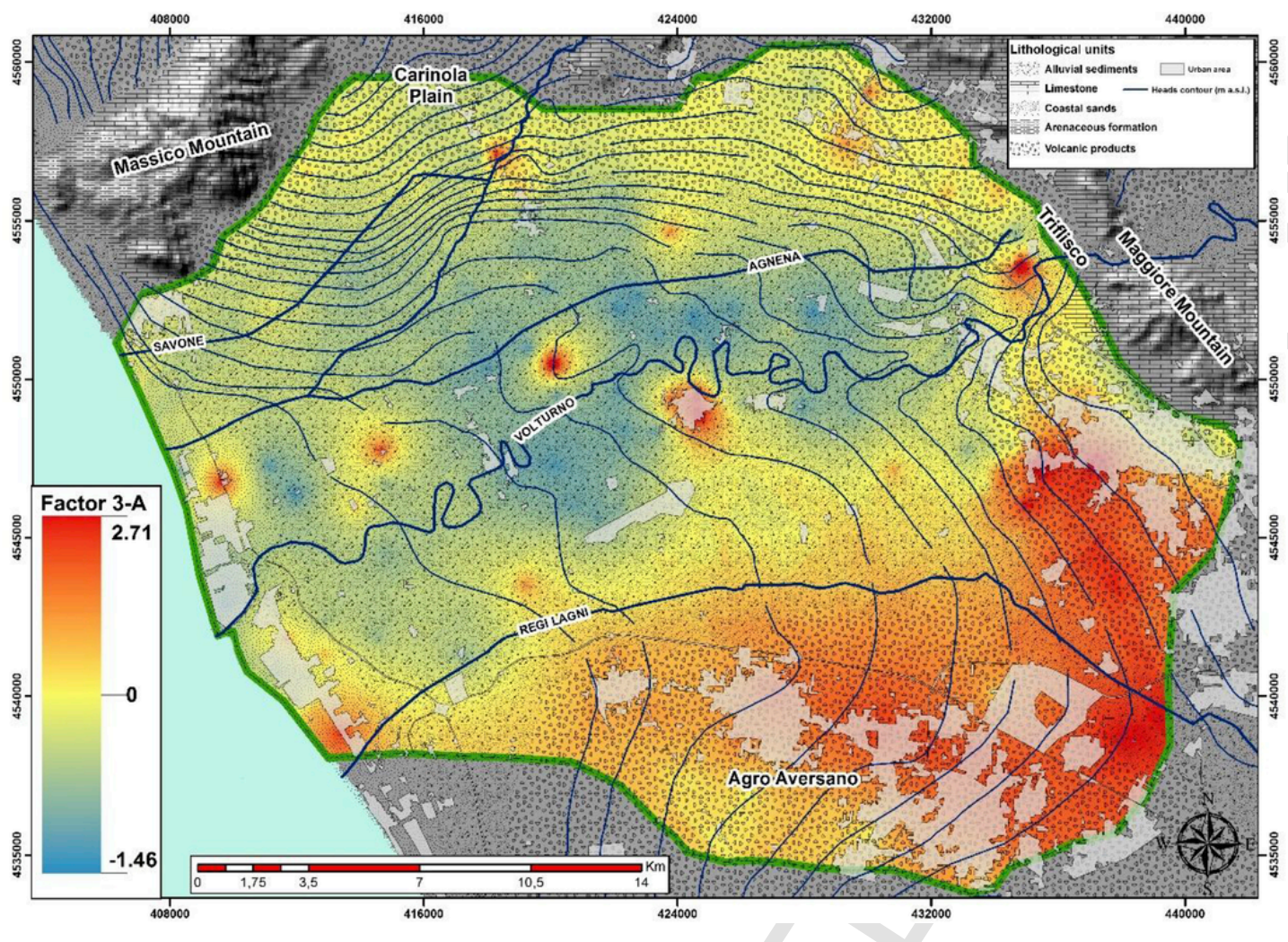

Fig. 5. Spatial distribution of Factor 3 (FA-A).

Table 2

Factor score of FA-B.

\begin{tabular}{|c|c|c|c|c|c|}
\hline \multirow[t]{2}{*}{ FA-B } & \multicolumn{5}{|c|}{ Component } \\
\hline & 1 & 2 & 3 & 4 & 5 \\
\hline $\mathrm{Li}$ & 0.077 & -0.014 & 0.072 & -0.071 & 0.843 \\
\hline B & 0.760 & -0.014 & -0.033 & 0.320 & -0.136 \\
\hline V & -0.435 & -0.049 & 0.079 & -0.354 & -0.444 \\
\hline $\mathrm{Cr}$ & -0.079 & 0.027 & 0.795 & 0.257 & -0.036 \\
\hline $\mathrm{Mn}$ & 0.334 & 0.782 & -0.003 & 0.223 & -0.056 \\
\hline $\mathrm{Fe}$ & 0.016 & 0.911 & -0.007 & -0.051 & 0.042 \\
\hline $\mathrm{Ni}$ & 0.061 & -0.023 & 0.773 & 0.089 & 0.099 \\
\hline As & -0.039 & 0.020 & 0.181 & 0.621 & 0.146 \\
\hline $\mathrm{Rb}$ & 0.173 & 0.089 & 0.093 & 0.827 & -0.150 \\
\hline $\mathrm{Sr}$ & 0.864 & 0.089 & 0.153 & -0.144 & 0.130 \\
\hline $\mathrm{U}$ & 0.301 & -0.040 & 0.521 & -0.329 & -0.449 \\
\hline $\mathrm{Ba}$ & 0.740 & 0.346 & -0.019 & -0.001 & 0.110 \\
\hline
\end{tabular}

iii) Anthropogenic sources of pollution $\left(\mathrm{NO}_{3}{ }^{-}, \mathrm{SO}_{4}{ }^{2-}, \mathrm{U}, \mathrm{V}\right)$ iv) $\mathrm{Re}-$ ducing conditions ( $\mathrm{Fe}, \mathrm{Mn}), \mathrm{v})$ Natural origin ( $\mathrm{Cr}$ and $\mathrm{Ni}$ ), vi) Geothermal fluids influence (Li), and vii) Volcanic products contribution (As, Rb).

Salinization is described by factors 1-A and 1-C. The map in Fig. 3 shows that all chemical variables enclosed in the Factor 1-A are inversely correlated with the blue shaded areas at N-NE of the CP because of the lateral recharge from carbonatic massifs, thus with a strong $\mathrm{Ca}(\mathrm{Mg})-\mathrm{HCO}_{3}$ predominance. In the S-SW part of the $\mathrm{CP}$ groundwater undergoes different processes due to the interaction with siliceous porous media (both volcanic and alluvial sediments). Ion exchange, glass alteration and feldspar weathering explain the $\mathrm{Na}^{+}$ and $\mathrm{K}^{+}$increase (Hem, 1985; Thivya et al., 2013). The stronger influence of salinization is obviously located near the coastal area, where the presence of shallow marine sediments in proximity of the
Table 3

Factor score of FA-C.

\begin{tabular}{|c|c|c|c|c|c|c|}
\hline FA-C & Compo & & & & & \\
\hline 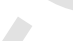 & 1 & 2 & 3 & 4 & 5 & 6 \\
\hline $\mathrm{pH}$ & 0.537 & -0.152 & -0.414 & 0.071 & 0.314 & 0.045 \\
\hline $\mathrm{EC}$ & 0.789 & 0.535 & 0.119 & 0.124 & 0.038 & 0.079 \\
\hline $\mathrm{HCO}_{3}$ & 0.471 & 0.643 & -0.288 & 0.220 & -0.065 & 0.131 \\
\hline $\mathrm{Cl}$ & 0.831 & 0.253 & -0.027 & 0.026 & -0.005 & -0.007 \\
\hline $\mathrm{NO}_{3}$ & -0.132 & -0.113 & 0.774 & -0.112 & 0.166 & -0.076 \\
\hline $\mathrm{SO}_{4}$ & 0.280 & 0.381 & 0.606 & -0.077 & 0.257 & 0.055 \\
\hline $\mathrm{Na}$ & 0.921 & 0.119 & -0.041 & 0.040 & -0.001 & 0.121 \\
\hline $\mathrm{K}$ & 0.463 & -0.036 & 0.389 & 0.129 & -0.015 & 0.030 \\
\hline $\mathrm{Mg}$ & 0.366 & 0.820 & -0.084 & 0.052 & 0.011 & 0.012 \\
\hline $\mathrm{Ca}$ & 0.001 & 0.850 & 0.068 & 0.114 & 0.089 & 0.018 \\
\hline $\mathrm{Li}$ & -0.140 & 0.642 & -0.140 & -0.171 & -0.193 & 0.362 \\
\hline B & 0.782 & 0.202 & -0.166 & 0.094 & 0.058 & -0.110 \\
\hline V & -0.186 & -0.259 & 0.645 & -0.069 & -0.191 & 0.005 \\
\hline $\mathrm{Cr}$ & 0.020 & -0.035 & 0.019 & -0.017 & 0.794 & 0.230 \\
\hline $\mathrm{Mn}$ & 0.310 & 0.136 & -0.082 & 0.783 & 0.007 & 0.114 \\
\hline $\mathrm{Fe}$ & -0.059 & 0.048 & -0.028 & 0.868 & -0.064 & 0.053 \\
\hline $\mathrm{Ni}$ & 0.044 & 0.058 & 0.030 & -0.041 & 0.722 & 0.060 \\
\hline As & 0.021 & 0.095 & -0.027 & 0.090 & 0.183 & 0.704 \\
\hline $\mathrm{Rb}$ & 0.542 & -0.069 & -0.046 & 0.123 & 0.205 & 0.579 \\
\hline $\mathrm{Sr}$ & 0.361 & 0.701 & 0.074 & 0.195 & 0.161 & -0.297 \\
\hline $\mathrm{U}$ & 0.035 & 0.141 & 0.448 & 0.078 & 0.465 & -0.330 \\
\hline $\mathrm{Ba}$ & 0.312 & 0.469 & -0.262 & 0.455 & 0.116 & -0.276 \\
\hline
\end{tabular}

Volturno River mouth together with the actual seawater intrusions increase $\mathrm{EC}, \mathrm{pH}, \mathrm{Na}^{+}$and $\mathrm{Cl}^{-}$in groundwater.

The water-carbonate rocks interaction (Fig. 4) is described in both FA-A and FA-C (Factors 2-A and 2-C). The contribution from the carbonatic reliefs towards the shallow aquifer of the $\mathrm{CP}$ is well known and confirmed by hydrogeological studies (Allocca et al., 2007). It is worth to mention that several mineralized springs are pre- 
sent in the area between Mt. Massico and the Volturno River (Cuoco et al., 2015a). All these mineral waters are $\mathrm{CaCO}_{3}$ saturated and generally mix in the groundwater of the shallow aquifer, which is recharged by rainfall. The aforementioned processes and findings from previous studies, confirm the spatial extent of carbonate rocks impact on groundwater quality in the $\mathrm{CP}$, as depicted from the FA in this study.

Anthropogenic impact in the CP are mainly due to the use of fertilizers in agriculture, in countryside as well as in suburban areas (Busico et al., 2017), manure from livestock activities and sewers leakage (Cuoco et al., 2017a). Factors 3-A and 3-C describe the anthropogenic sources of pollution in the study area (Fig. 5). Accordingly, previous studies linked high $\mathrm{NO}_{3}{ }^{-}$and $\mathrm{SO}_{4}{ }^{2-}$ concentrations to anthropogenic activities, like for example the continuous use of fertilizers such as NPK (Cuoco et al., 2015b; Huan et al., 2012; Shrestha et al., 2017). In particular, $\mathrm{KNO}_{3}$ is highly water-soluble and it can be easily leached to groundwater (El Alfy et al., 2017; Kim et al., 2009b). Despite $\mathrm{K}^{+}$is usually retarded with respect to $\mathrm{NO}_{3}{ }^{-}$due to cation exchange, on a long-term basis also $\mathrm{K}^{+}$can be leached through permeable soils (Griffioen, 2001). In this study, a moderate correlation of $\mathrm{V}$ and $\mathrm{U}$ with $\mathrm{NO}_{3}{ }^{-}, \mathrm{SO}_{4}{ }^{2-}$ and $\mathrm{K}^{+}$has been found. Previous works on the area, demonstrated how $\mathrm{U}$ is connected to anthropogenic pollution (Cuoco et al., 2015b), mainly from phosphate fertilizers. Liesch et al. (2015) have also linked U concentration with phosphate fertilizers in Baden-Württemberg, Germany.

Similarly, V can be present in organic (animal manure) and inorganic fertilizers too (Mortvedt, 1995). Regarding the processes involving $\mathrm{V}$, further analysis on soil (SEM) and leaching tests could better explain the observed conditions, identifying the mineralogical and amorphous phases in which $\mathrm{V}$ could be included.
Reducing conditions occur within the aquifer in the central part of the basin, due to the presence of peat layers. FA helps to describe the reducing conditions in factors $2-\mathrm{B}$ and $4-\mathrm{C}$ reporting high loads of $\mathrm{Fe}$ and $\mathrm{Mn}$. The highest scores can be found in the area near the Volturno River (Fig. S2) due to the presence of peat layers and high levels of organic matter, which usually lead to strong reducing conditions (Corniello et al., 2010; Kehew, 2001; Mastrocicco et al., 2013). The low concentrations of $\mathrm{NO}_{3}^{-}$found in these areas $\left(<10 \mathrm{mg} \mathrm{L}^{-1}\right)$ despite the land use is prevalently agricultural, support this conclusion.

Surprisingly, the multivariate statistical analysis has also revealed factors (namely, factors 3-B and 5-C) with high loading of $\mathrm{Cr}$ and $\mathrm{Ni}$. The main geogenic source of $\mathrm{Cr}$ in the $\mathrm{CP}$ are ophiolitic rocks and specifically their serpentinized by-products and their weathering products (Nriagu and Nieboer, 1988). Nonetheless, anthropogenic sources can also contribute to the current balance of $\mathrm{Cr}$ and $\mathrm{Ni}$. In fact, paint production, mining activities and phosphate fertilizers production and use (Molina et al., 2009), as well as coal combustion and the uncontrolled disposal of fly ash (Jacobs and Testa, 2004) may be other possible sources. Kazakis et al. (2017b) used FA in order to distinguish geogenic (ophiolitic rocks) and anthropogenic (fly ash dispersion) origin in the Sarigkiol (GR) basin. In CP the positive correlation of $\mathrm{Cr}$ with $\mathrm{Ni}$ in groundwater suggests a geogenic origin of $\mathrm{Cr}$. In addition, the low Ni background and $\mathrm{Cr}$ concentrations in $\mathrm{CP}$ soils support the geogenic origin for both these trace elements (Cicchella et al., 2015; Morrison et al., 2015; Rezza et al., 2017).

Another process identified from FA explains the occurrence of a hydrothermal system in the Mondragone plain (Cuoco et al., 2015a). The process is only described by the FA using trace elements and specifically by Factor 5-B (Fig. S1). Li is found in high concentrations in thermal waters (Sánchez-Martos et al., 2002), where the mo-

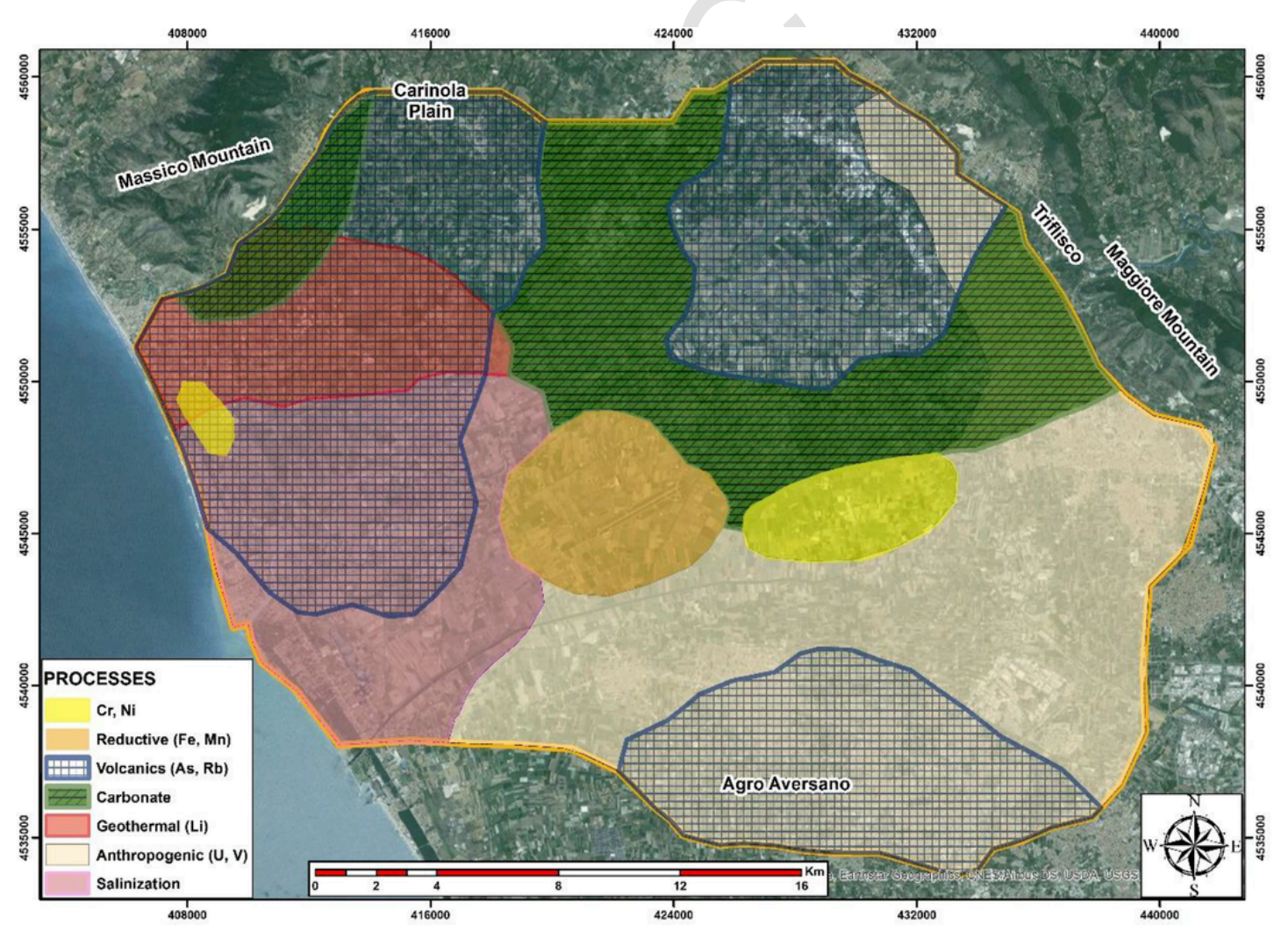

Fig. 6. Summary of chemical processes in the study area. 
bility of $\mathrm{Li}$ is related to temperature (Chan et al., 1994). In the application of FA using all the dissolved species Li was included in Factor 2-C, which mainly explains the carbonate rocks/products interaction with groundwater. The last process is the concurring presence of both As and $\mathrm{Rb}$, which highlights the influence of volcanic rock products in the area (Fig. S4). Both elements originate from volcanic rocks and groundwater interactions. Casentini et al. (2010) related As concentrations in groundwater to volcanic rocks, such as lava and tuff. From the geological map in Fig. 1 it is possible to appreciate how the CP is recharged from the Roccamonfina Volcano to the $\mathrm{N}$ and from the volcanic aquifer of Agro Aversano to the S.

In Fig. 6 all the geochemical and anthropogenic processes insisting on the CP unconfined aquifer are shown. It is worth mentioning that the boundary of each process could not clearly be defined because mixing phenomena also occur within the aquifer. Therefore, buffer zones where more than one hydrochemical process exists are shown in Fig. 6. The innovative approach of this study highlighted the necessity to perform FA using all datasets together, as well as separately, in order to identify all the hydrochemical processes occurring at the aquifer scale.

The application of the three different approaches regarding FA revealed the main processes insisting in the CP. The robustness of the selected methodology has been verified by the major hydrochemical processes that were identified in the aquifer, showing high consistency with previous studies. However, future determinations and elaborations of geochemical and mineralogical data from both CP rocks and sediments will supplement and reinforce the results of this study.

\section{Conclusions}

The application of the FA to different data sets (A, B, C) depicted all hydrogeochemical processes acting in the study area. In particular, seven main processes responsible for the current hydrochemical regime of the local shallow aquifer were identified. They can be summarized as follow: i) Salinization $\left(\mathrm{Cl}^{-}, \mathrm{Na}^{+}\right)$, ii) Carbonate rocks influences, iii) Anthropogenic sources of pollution $\left(\mathrm{NO}_{3}{ }^{-}, \mathrm{SO}_{4}{ }^{2-}, \mathrm{U}, \mathrm{V}\right)$ iv) Reducing conditions (Fe, Mn), v) Natural sources (Cr, Ni), vi) Geothermal fluids influence (Li), and vii) Volcanic products contribution (As, Rb).

Regarding the trace elements, As is related to volcanic rocks leaching, $\mathrm{U}$ and $\mathrm{V}$ are linked to the use of fertilizers, and $\mathrm{Li}$ is associated with geothermal activities. However, the impact of geothermal fluids, in the shallow aquifer was identified only by applying the FA with the trace elements database. Beyond the details of the hydrogeochemical processes in the $\mathrm{CP}$, in this study we highlighted the need to apply FA separately when a large data set of trace elements is available.

Results of this study can be widely used in complex aquifers in order to distinguish between different hydrogeochemical processes, and possibly preventing local populations from future exposure to potentially toxic elements.

\section{Acknowledgements}

Dr. Maurizio Sirna is acknowledged for helping in reconstructing the geological setting of the area.

\section{Appendix A. Supplementary data}

Supplementary data related to this article can be found at https:// doi.org/10.1016/j.envpol.2017.11.053.

\section{References}

Allocca, V., Celico, F., Celico, P., De Vita, P., Fabbrocino, S., Mattia, C., Monacelli, G., Musilli, I., Piscopo, V., Scalise, A.R., Summa, G., Tranfaglia, G., 2007. Carta Idrogeologica dell'Italia Meridionale. Istituto Poligrafico e Zecca dello Stato.

Amorosi, A., Pacifico, A., Rossi, V., Ruberti, D., 2012. Late Quaternary incision and deposition in an active volcanic setting: the Volturno valley fill, Southern Italy. Sedim. Geol. 282, 307-320. https://doi.org/10.1016/j.sedgeo.2012.10.003.

Anazawa, K., Ohmori, H., 2005. The hydrochemistry of surface watersin Andesitic Volcanic area, Norikura volcano, central Japan. Chemosphere 59, 605-615. https:// doi.org/10.1016/j.chemosphere.2004.10.018.

Back, W., Hanshaw, B.B., 1965. Chemical geohydrology. Adv. Hydrosci. 2, 49-109.

Batabyal, A.K., 2014. Correlation and multiple linear regression analysis of groundwater quality data of Bardhaman district, West Bengal, India. Int. J. Res. Chem. Environ. $4(4), 42-51$.

Belkhiri, L., Boudoukha, A., Mouni, L., Baouz, T., 2010. Application of multivariate statistical methods and inverse geochemical modeling for characterization of groundwater a case study: ain Azel plain (Algeria). Geoderma 159, 390-398. https: //doi.org/10.1016/j.geoderma.2010.08.016.

Brown, C.E., 1998. Applied Multivariate Statistics in Geohydrology and Related Sciences. Springer, New York.

Busico, G., Kazakis, N., Colombani, N., Mastrocicco, M., Voudouris, K., Tedesco, D., 2017. A modified SINTACS method for groundwater vulnerability and pollution risk assessment in highly anthropized regions based on $\mathrm{NO}_{3}{ }^{-}$and $\mathrm{SO}_{4}{ }^{2-}$ concentrations. Sci. Total Environ. 609, 1512-1523, DOI: doi.org/10.1016/j.scitotenv.2017.07.257.

Casciello, E., Cesarano, M., Pappone, G., 2006. Extensional detachment faulting on the Tyrrhenian margin of the southern Apennines contractional belt (Italy). J. Geol. Soc. 163 (4), 617-629. https://doi.org/10.1144/0016-764905-054.

Casentini, B., Pettine, M., Millero, F., 2010. Release of arsenic from volcanic rocks through interactions with inorganic anions and organic ligands. Aquat. Geochem 16 (3), 373-393. https://doi.org/10.1007/s10498-010-9090-3.

Chan, L., Gieskes, J.M., You, C., Edmond, J.M., 1994. Lithium isotope geochemistry of sediments and hydrothermal fluids of the Guayamas Basin, Gulf of California. Geochim. Cosmochim. Acta 58, 4443-4454. https://doi.org/10.1016/ 0016-7037(94)90346-8.

Cicchella, D., Giaccio, L., Dinelli, E., Albanese, S., Lima, A., Zuzolo, D., De Vivo, B., 2015. GEMAS: spatial distribution of chemical elements in agricultural and grazing land soil of Italy. J. Geochem. Explor 154, 129-142. https://doi.org/10.1016/j. gexplo.2014.11.009.

Corniello, A., Ducci, D., Ruggieri, G., 2007. Areal identification of groundwater nitrate contamination sources in periurban areas. J. Soils Sediments 7 (4), 159-166. https://doi.org/10.1065/jss2007.03.213.

Corniello, A., Ducci, D., Rotella, M., Trifuoggi, M., Ruggieri, G., 2010. Hydrogeology and hydrogeochemistry of the plain between Mt. Massico and the river Volturno (Campania region, Italy). Ital. J. Eng. Geol. Environ. 1, 51-64. https://doi.org/10. 4408/IJEGE.2010-01.O-04.

Corniello, A., Ducci, D., 2014. Hydrogeochemical characterization of the main aquifer of the "litorale domizio - Agro Aversano nips" (Campania - southern Italy). J. Geochem. Explor 137, 1-10. https://doi.org/10.1016/j.gexplo.2013.10.016.

Cuoco, E., Colombani, N., Darrah, T.H., Mastrocicco, M., Tedesco, D., 2017a. Geolithological and anthropogenic controls on the hydrochemistry of the Volturno river (Southern Italy). Hydrol. Process 31 (3), 627-638. https://doi.org/10.1002/ hyp. 11055 .

Cuoco, E., Darrah, T.H., Buono, G., Eymold, W.K., Tedesco, D., 2015a. Differentiating natural and anthropogenic impacts on water quality in a hydrothermal coastal aquifer (Mondragone plain, Southern Italy). Environ. Earth Sci. 73 (11), 7115-7134. https://doi.org/10.1007/s12665-014-3892-3.

Cuoco, E., Darrah, T.H., Buono, G., Verrengia, G., De Francesco, S., Eymold, W.K., Tedesco, D., 2015b. Inorganic contaminants from diffuse pollution in shallow groundwater of the Campanian plain (southern Italy). Implications for geochemical survey. Environ. Monit. Assess. 187 (2), 46. https://doi.org/10.1007/ s10661-015-4307-y.

Cuoco, E., Minissale, A., Di Leo, A., Tamburrino, S., Iorio, M., Tedesco, D., 2017 b. Fluid geochemistry of the Mondragone hydrothermal systems (southern Italy): water and gas compositions vs. geostructural setting. Int. J. Earth Sci. https://doi.org/ 10.1007/s00531-016-1439-4, Article (in press)

Cuoco, E., Tedesco, D., Poreda, R.J., Williams, J.C., De Francesco, S., Balagizi, C., Darrah, T.H., 2013. Impact of volcanic plume emissions on rain water chemistry during the January 2010 Nyamuragira eruptive event: implications for essential potable water resources. J. Hazard. Mat. 244-245, 570-581. https://doi.org/10. 1016/j.jhazmat.2012.10.055.

De Vivo, B., Rolandi, G., Gans, P.B., Calvert, A., Bohrson, W.A., Spera, F.J., Belkin, H.E., 2001. New constraints on the pyroclastic eruptive history of Campanian volcanic Plain (Italy). Mineral. Pet. 73, 47-65. https://doi.org/10.1007/ s007100170010. 
Einax, J.W., Zwanziger, H.W., Geib, S., 1997. Chemometrics in Environmental Analysis. VCH, Weinheim.

El Alfy, M., Lashin, A., Abdalla, F., Al-Bassam, A., 2017. Assessing the hydrogeochemical processes affecting groundwater pollution in arid areas using an integration of geochemical equilibrium and multivariate statistical techniques. Environ. Pollut. 229, 760-770. https://doi.org/10.1016/j.envpol.2017.05.052.

Foster, S.S.D., Chilton, P.J., 2003. Groundwater: the processes and global significance of aquifer degradation. Philos. Trans. R. Soc. Lond. B Biol. Sci. 358 (1440), 1957-1972. https://doi.org/10.1098/rstb.2003.1380.

Griffioen, J., 2001. Potassium adsorption ratios as an indicator for the fate of agricultural potassium in groundwater. J. Hydrol. 254 (1), 244-254. https://doi.org/10. 1016/S0022-1694(01)00503-0.

Hem, J.D., 1985. Study and interpretation of the chemical characteristics of natural water. U. S. Geol. Surv. Water Supply 2254, 117-120.

Huan, H., Jinsheng, W., Yanguo, T., 2012. Assessment and validation of groundwater vulnerability to nitrate based on a modified DRASTIC model: a case study in Jilin City of northeast China. Sci. Tot. Environ. 440, 14-23. https://doi.org/10.1016/j. scitotenv.2012.08.037

Huang, P., Wang, X., 2017. Applying environmental isotope theory to groundwater recharge in the jiaozuo mining area, China. Geofluids https://doi.org/10.1155/ 2017/9568349, Article ID 9568349.

Jacobs, J., Testa, S., 2004. Overview of chromium (VI) in the environment: background and history. In: Guertin, J., Jacobs, J., Avakian, C. (Eds.), Chromium (VI) Handbook. CRC Press, New York.

Kaiser, H.F., 1958. Thevarimax criterion for analytic rotation in factor analysis. Psychometrika 23, 187-200.

Kazakis, N., Kantiranis, N., Kalaitzidou, K., Kaprara, E., Mitrakas, M., Frei, R., Vargemezis, G., Tsourlos, P., Zouboulis, A., Filippidis, A., 2017a. Origin of hexavalent chromium in groundwater: the example of Sarigkiol Basin. North. Greece. Sci. Tot. Environ. 593-594, 552-566. https://doi.org/10.1016/j.scitotenv.2017.03. 128.

Kazakis, N., Mattas, C., Pavlou, A., Patrikaki, O., Voudouris, K., 2017b. Multivariate statistical analysis for the assessment of groundwater quality under different hydrogeological regimes. Environ. Earth Sci. 76 (9), 349. https://doi.org/10.1007/ s12665-017-6665-y.

Kehew, A.E., 2001. Applied Chemical Hydrogeology. Prentice Hall.

Kim, K., Moon, J.T., Kim, S.H., Ko, K.S., 2009a. Importance of surface geologic conditioning regulating as concentration of groundwater in the alluvial plain. Chemosphere 77, 478-484. https://doi.org/10.1016/j.chemosphere.2009.07.

Kim, K., Yun, S., Choi, B., Chae, G., Joo, Y., Kim, K., Kim, H., 2009b. Hydrochemical and multivariate statistical interpretations of spatial controls of nitrate concentrations in a shallow alluvial aquifer around oxbow lakes (Osong area, central Korea). J. Cont. Hydrol. 107 (3-4), 114-127. https://doi.org/10.1016/j.jconhyd.2009. 04.007.

Kumar, P., 2014. Evolution of groundwater chemistry in and around Vaniyambadi industrial area: differentiating the natural and anthropogenic sources of contamination. Chem. Erde 74, 641-651. https://doi.org/10.1016/j.chemer.2014.02.002.

Liesch, T., Hinrichsen, S., Goldscheider, N., 2015. Uranium in groundwater-Fertilizer versus geogenic sources. Sci. Tot. Environ. 536, 981-995. https://doi.org/10.1016/ j.scitotenv.2015.05.133

Liu, C., Lin, K., Kuo, Y., 2003. Application of factor analysis in the assessment of groundwater quality in a blackfoot disease area in Taiwan. Sci. Tot. Environ. 313, 77-89. https://doi.org/10.1016/S0048-9697(02)00683-6.

Locsey, K.L., Cox, M.E., 2003. Statistical and hydrochemical methods to compare basalt- and basement rock-hosted groundwaters: atheron Tablelands, northeastern Australia. Environ. Geol. 43 (6), 698-713. https://doi.org/10.1007/ s00254-002-0667-z.

Mastrocicco, M., Colombani, N., Di Giuseppe, D., Faccini, B., Ferretti, G., Coltorti, M., 2016. Abnormal trace element concentrations in a shallow aquifer belonging to saline reclaimed environments, Codigoro (Italy). Rendiconti Lincei 27 (1), 95-104. https://doi.org/10.1007/s12210-015-0454-x.

Mastrocicco, M., Giambastiani, B.M.S., Colombani, N., 2013. Ammonium occurrence in a salinized lowland coastal aquifer (Ferrara, Italy). Hydrol. Proces. 27 (24), 3495-3501. https://doi.org/10.1002/hyp.9467.

Mokrik, R., Karro, E., Savitskaja, L., Drevaliene, G., 2009. The origin of barium in the cambrian-vendian aquifer system, North Estonia. Est. J. Earth Sci. 58 (3), 193-208. https://doi.org/10.3176/earth.2009.3.04.

Molina, M., Aburto, F., Calderón, R., Cazanga, M., Escudey, M., 2009. Trace element composition of selected fertilizers used in Chile: phosphorus fertilizers as a source of long term soil contamination. Soil sedim. Cont. 18, 497-511, DOI: 10. 1080/ 15320380902962320 .

Morrison, J., Goldhaber, M., Mills, Christopher, Breit, G., Hooper, R., Holloway, J., Diehl, S., Ranville, J., 2015. Weathering and transport of chromium and nickel from serpentinite in the coast range ophiolite to the Sacramento Valley, Ca, USA Appl. Geochem 61, 72-86. https://doi.org/10.1016/j.apgeochem.2015.05.018.

Mortvedt, J.J., 1995. Heavy metal contaminants in inorganic and organic fertilizers. Fertil. Res. 43 (1), 55-61. https://doi.org/10.1007/BF00747683.

Niu, B., Wang, H., Loáiciga, H.A., Hong, S., Shao, W., 2017. Temporal variations of groundwater quality in the western jianghan plain, China. Sci. Tot. Environ. 578, 542-550. https://doi.org/10.1016/j.scitotenv.2016.10.225.

Nriagu, J.O., Nieboer, E., 1988. Chromium in the Natural and Human Environments. Wiley-Interscience, New York, 466.

Pereira, H.G., Renca, S., Sataiva, J., 2003. A case study on geochemical anomaly identification through principal component analysis supplementary projection. Appl. Geochem 18, 37-44. https://doi.org/10.1016/S0883-2927(02)00099-9.

Piper, A.M., 1944. A graphical procedure in the geochemical interpretation of water analysis. Trans. Am. Geophys. Union 25, 914-923. https://doi.org/10.1029/ TR025i006p00914.

Rezza, C., Albanese, S., Ayuso, R., Lima, A., Sorvari, J., De Vivo, B., 2017. Geochemical and $\mathrm{Pb}$ isotopic characterization of soil, groundwater, human hair, and corn samples from the Domizio Flegreo and Agro Aversano area (Campania region, Italy). J. Geochem. Explor https://doi.org/10.1016/j.gexplo.2017.01.007, Article (in press)

Rolandi, G., Bellucci, F., Heizler, M.T., Belkin, H.E., De Vivo, B., 2003. Tectonic controls on the genesis of ignimbrites from the Campanian Volcanic Zone, southern Italy. Mineral. Pet. 79 (1-2), 3-31. https://doi.org/10.1007/s00710-003-0014-4.

Sánchez-Martos, F., Pulido-Bosch, A., Molina-Sánchez, L., Vallejos-Izquierdo, A., 2002. Identification of the origin of salinization in groundwater using minor ions (Lower Andarax, southeast Spain). Sci. Tot. Environ. 297 (1-3), 43-58. https://doi. org/10.1016/S0048-9697(01)01011-7.

Santangelo, N., Romano, P., Ascione, A., Russo Ermolli, E., 2017. Quaternary evolution of the Southern Apennines coastal plains: a review. Geol. Carpath. 68 (1), 43-56. https://doi.org/10.1515/geoca-2017-0004

Shrestha, S., Kafle, R., Pandey, V.P., 2017. Evaluation of index-overlay methods for groundwater vulnerability and risk assessment in Kathmandu valley. Nepal. Sci. tot. Environ. 575, 779-790. https://doi.org/10.1016/j.scitotenv.2016.09.141.

Thivya, C., Chidambaram, S., Singaraja, C., Thilagavathi, R., Prasanna, M.V., Jainab, I., 2013. A study on the significance of lithology in ground-water quality of Madurai district, Tamil Nadu (India). Environ. Develop. Sus 15 (5), 1365-1387. https:// doi.org/10.1007/s10668-013-9439-z.

Ujević Bošnjak, M., Capak, K., Jazbec, A., Casiot, C., Sipos, L., Poljak, V., Dadić, , 2012. Hydrochemical characterization of arsenic contaminated alluvial aquifers in Eastern Croatia using multivariate statistical techniques and arsenic risk assessment. Sci. Tot. Environ. 420, 100-110. https://doi.org/10.1016/j.scitotenv.2012.01. 021 .

Voudouris, K., Lambrakis, N., Papatheodorou, G., Daskalaki, P., 1997. An application of factor analysis for the study of the hydrogeological conditions in Plio-Pleistocene aquifers of NW Achaia (NW Peloponnesus, Greece). Math. Geol. 29 (1), 43-59. https://doi.org/10.1007/BF02769619.

Voudouris, K., Panagopoulos, A., Koumantakis, J., 2000. Multivariate statistical analysis in the assessment of hydrochemistry of the northern Korinthia prefecture alluvial aquifer system (Peloponnese, Greece). Nat. Resour. Res. 9 (2), 135-146. https: //doi.org/10.1023/A:1010195410646.

Wang, Y., Ma, T., Luo, Z., 2001. Geostatistical and geochemical analysis of surface water leakage into groundwater on a regional scale: a case study in the Liulin karst system, north-western China. J. Hydrol. 246 (1-4), 223-234. https://doi.org/10. 1016/S0022-1694(01)00376-6.

Yang, Q., Li, Z., Ma, H., Wang, L., Martin, J.D., 2016. Identification of the hydrogeochemical processes and assessment of groundwater quality using classic integrated geochemical methods in the southeastern part of Ordos basin, China. China. Environ. Pollut. 218, 879-888. https://doi.org/10.1016/j.envpol.2016.08.017.

Zieliński, M., Dopieralska, J., Belka, Z., Walczak, A., Siepak, M., Jakubowicz, M., 2017. The strontium isotope budget of the Warta River (Poland): between silicate and carbonate weathering, and anthropogenic pressure. Appl. Geochem 81, 1-11. https://doi.org/10.1016/j.apgeochem.2017.03.014. 